\title{
Event Free Survival Enam Bulan Kejadian Tumor Gachexia Syndrome pada Anak dengan Keganasan
}

\author{
Hesti Kartika Sari, Maria Mexitalia, Yetty M Nency \\ Bagian Ilmu Kesehatan Anak Fakultas Kedokteran Universitas Diponegoro/RSUP dr. Kariadi, \\ Semarang
}

\begin{abstract}
Latar belakang. Jumlah kasus kanker pada anak dengan komplikasi tumor cachexia syndrome (TCS) terus meningkat. Penyebab TCS bersifat multifaktorial, yaitu asupan makanan yang kurang, malabsorbsi, dan sitokin oleh tumor. Pengelolaan pasien anak dengan keganasan di rumah sakit tidak hanya dari terapi anti kanker tetapi juga nutrisi. Nilai event free survival (EFS) terhadap kejadian TCS merupakan salah satu indikator keberhasilan pengelolaan kanker di rumah sakit.

Tujuan. Menentukan EFS 6 bulan terhadap kejadian TCS pada pasien anak dengan keganasan.

Metode. Desain kohort retrospektif berdasarkan catatan medik pasien anak dengan keganasan yang dirawat di RSUP Dr. Kariadi Semarang pada bulan Januari 2007 - Desember 2012. Kriteria inklusi adalah pasien usia 0-14 tahun, dengan diagnosis keganasan baik tumor padat maupun hematologi, dan tidak mengalami kakeksia pada saat diagnosis ditegakkan. Dilakukan pengamatan secara klinis dan laboratoris tiap bulan selama 6 bulan untuk menentukan terjadinya TCS. Analisis statistik menggunakan uji Kaplan Meier.

Hasil. Didapatkan 83 subjek dengan keganasan, rerata umur pada kelompok tumor padat 61,2 (SD 48,37) bulan, dan keganasan hematologi 79,9 (SD 48,37) bulan p=0,032. Empatbelas dari 40 (35\%) anak tumor padat dan 10 dari 43(23,3\%) anak dengan keganasan hematologi mengalami TCS. Kejadian TCS didapatkan mulai pengamatan bulan kedua. Rerata terjadi TCS pada tumor padat 4,4 bulan dan pada keganasan hematologi 4,9 bulan. Event free survival 6 bulan kejadian TCS pada tumor padat $65 \%$ dan keganasan hematologi 76,7\%, $\mathrm{p}=\mathbf{0 , 2 0 7}$.

Kesimpulan. Event free survival 6 bulan kejadian TCS pada pasien tumor padat lebih rendah daripada keganasan hematologi, tetapi tidak berbeda secara statistik. Sari Pediatri 2015;16(6):397-402.
\end{abstract}

Kata kunci: event free survival (EFS), tumor chachexia syndrome (TCS), keganasan anak

\footnotetext{
Alamat korespondensi:

Dr. Hesti Kartika Sari, SpA. RSUD RAA Soewondo, Margorejo, Pati. Email: hesti.hasyim@idai.or.id, hesti.hasyim@gmail.com
}

umlah kasus kanker anak dengan komplikasi tumor cachexia syndrome (TCS) terus meningkat, dengan prevalensi $24 \%$ pada stadium dini dan lebih dari $80 \%$ pada stadium lanjut. ${ }^{1-4}$ Tumor cachexia syndrome adalah 
sindrom yang kompleks, meliputi keadaan malnutrisi yang ditandai dengan anoreksia, penurunan berat badan, muscle wasting, lipolisis, kehilangan masa otot dan protein viseral, asthenia, depresi, nausea kronik, hipoalbuminemia dan anemia yang menyebabkan stres psikologis, perubahan dalam komposisi tubuh, gangguan dalam metabolisme karbohidrat, lemak dan protein, cairan jaringan, keseimbangan asam basa, kadar vitamin dan elektrolit. ${ }^{1,2}$ Tumor cachexia syndrome berhubungan dengan morbiditas, mortalitas, serta penurunan kualitas dan daya tahan hidup pasien. ${ }^{4-8}$

Penyebab TCS pada kanker bersifat multifaktorial. ${ }^{1,6}$ Secara umum, dikelompokkan menjadi 3 kategori, yaitu asupan makanan yang kurang, malabsorbsi, dan pengaruh sitokin yang dihasilkan oleh tumor. ${ }^{1}$ Peneliti lain menyebutkan penyebab kakeksia pasien kanker adalah faktor psikologis dan susunan saraf pusat (keengganan makan dan perubahan ambang rasa), efek tumor (obstruksi mekanis, pemakaian substrat/nutrisi oleh tumor, produksi sitokin oleh sel tumor (IL1, IL6, TNF), efek yang berhubungan dengan terapi (kemoterapi, radiasi, bedah, nausea, stomatitis, xerostomia, nyeri, ileus) dan efek yang berhubungan dengan pasien (peningkatan resting energy expenditure, gangguan proses metabolisme, produksi sitokin oleh makrofag, disfungsi otonom, dan penurunan pengosongan lambung). ${ }^{6}$

Pelayanan paripurna pasien yang dirawat di rumah sakit pada dasarnya harus meliputi tiga hal, yaitu asuhan medis, asuhan keperawatan, dan asuhan nutrisi. ${ }^{9-11}$ Ketiga hal tersebut saling berkaitan satu sama lain dan merupakan bagian dari pelayanan medis yang tidak dapat dipisahkan. ${ }^{9}$ Asuhan nutrisi yang baik dapat mencegah seorang pasien menderita malnutrisi rumah sakit (MRS, hospital malnutrition) selama dalam perawatan, yang berdampak pada lamanya masa perawatan (lengthof-stay) serta morbiditas dan mortalitas pasien yang meningkat, berarti pula meningkatnya biaya yang harus dikeluarkan. ${ }^{11}$

Pengelolaan kanker tidak hanya dari terapi anti kanker, tetapi harus bersifat holistik dan komprehensif, meliputi juga aspek nutrisi dan psikologi. ${ }^{10}$ Semakin tinggi nilai event free survival (EFS) dari TCS, menunjukkan keberhasilan pengelolaan kanker di rumah sakit. Tujuan penelitian ini kami ingin menilai tingkat EFS 6 bulan dari TCS pada anak dengan keganasan.

\section{Metode}

Penelitian dilakukan secara kohort retrospektif dengan menggunakan data dari rekam medis. Subjek penelitian berusia 0-14 tahun dengan diagnosis keganasan baik tumor padat maupun keganasan hematologi dirawat di Rumah Sakit Umum Pusat dr. Kariadi Semarang pada bulan Januari 2007-Desember 2012.

Kriteria inklusi, tidak mengalami kakeksia pada saat diagnosis ditegakkan. Untuk kriteria eksklusi, jika pasien drop out, data yang tidak lengkap mengenai BB dan TB atau LiLA tiap bulan, dan albumin serum minimal satu kali dalam 6 bulan. Dilakukan pengamatan secara klinis dan laboratoris tiap bulan selama 6 bulan untuk menentukan terjadinya TCS dan menilai EFS terhadap TCS.

Definisi TCS yang dipakai adalah salah satu dari lima kriteria, yaitu keadaan penurunan BB lebih dari $5 \%$ dalam waktu 1 bulan, LiLA kurang dari persentil 5 menurut NHANES III, BB/TB kurang dari -2 SD, penurunan $\mathrm{BB} / \mathrm{TB}$ lebih dari 2 persentil mayor, dan klinis ditemukan muscle wasting, iga gambang, edema pitting, baggy pants ditambah dengan hipoalbuminemia di bawah $3,5 \mathrm{mg} / \mathrm{dL}$ baik dengan organomegali atau tanpa organomegali. Event free survival adalah keadaan pasien tidak mengalami TCS dalam batas waktu tertentu dan dinyatakan dalam persen. ${ }^{12}$

Uji statistik yang dilakukan adalah uji Kaplan Meier untuk menentukan EFS dari pasien keganasan. Log rank test digunakan untuk membandingkan kurva survival pada 2 kelompok. Nilai $\mathrm{p}<0,05$ menunjukkan hubungan yang bermakna.

\section{Hasil}

Penelitian analisis kesintasan untuk menilai kejadian EFS selama 6 bulan pada tumor padat dan hematologi anak. Didapatkan 388 pasien anak dengan keganasan yang dirawat di RSUP dr. Kariadi periode 2007-2012, terdiri atas 143 anak dengan tumor padat dan 245 dengan keganasan hematologi. Setelah melewati kriteria inklusi dan eksklusi, didapatkan sampel 83 anak, yang terdiri atas 40 dengan tumor padat dan 43 dengan keganasan hematologi. Karakteristik diagnosis dari 40 anak tumor padat didapatkan retinoblastoma 19 (47,5\%), limfoma maligna non Hodgkin (LMNH) $8(20 \%)$, nefroblastoma $6(15 \%)$, hepatoblastoma dan primitive neuro-ectodermal tumor (PNET) masing- 
Tabel 1. Karakteristik demografis subjek penelitian

\begin{tabular}{|c|c|c|c|}
\hline \multirow{2}{*}{ Variabel } & \multicolumn{2}{|c|}{ Frekuensi n, (\%) } & \multirow{2}{*}{$\mathrm{p}$} \\
\hline & Tumor padat $(\mathrm{n}=40)$ & Hematologi $(n=43)$ & \\
\hline \multicolumn{4}{|l|}{ Jenis kelamin } \\
\hline Laki-laki & $20(50)$ & $33(76,7)$ & $0,011^{*}$ \\
\hline Perempuan & $20(50)$ & $10(23,3)$ & \\
\hline \multicolumn{4}{|l|}{ Sosial ekonomi } \\
\hline Kurang & $37(92,5)$ & $40(93)$ & $1,000^{*}$ \\
\hline Cukup & $3(7,5)$ & $3(7,0)$ & \\
\hline \multicolumn{4}{|l|}{ Stadium } \\
\hline Dini & $30(75)$ & $36(83,7)$ & $0,449^{*}$ \\
\hline Lanjut & $10(25)$ & $7(16,3)$ & \\
\hline \multicolumn{4}{|l|}{ Netropenia } \\
\hline Tidak & $35(87,5)$ & $14(32,6)$ & $<0,001^{*}$ \\
\hline Ya & $5(12,5)$ & $29(67,4)$ & \\
\hline \multicolumn{4}{|l|}{ Gizi } \\
\hline Baik & $27(66)$ & $28(66)$ & $0,818^{*}$ \\
\hline Kurang & $13(34)$ & $15(34)$ & \\
\hline
\end{tabular}

Keterangan: ${ }^{*}$ chi-square test

masing 2 (5\%), dan astrositoma, malignant peripheral nerve sheath tumor (MPNST), neuroblastoma masingmasing 1 (2,5\%). Sementara itu, 43 anak dengan keganasan hematologi didapatkan acute lymphocytic leukemia (ALL) 33 (76,7\%), acute myelogenous leukemia (AML) 7 (16,3\%), chronic myeloid leukemia (CML) 2 (4,7\%), dan mixed leukemia 1 (2,3\%).

Rerata usia anak dengan tumor padat $61,2+48,37$ bulan dan pada keganasan hematologi 79,9+48,37 bulan $(p=0,032)$. Rerata onset gejala mulai timbulnya gejala keganasan awal sampai terdiagnosis pada kelompok tumor padat 10,5 bulan (SD 11,14) dan keganasan hematologi 3,02 bulan (SD 3,37), tetapi tidak berbeda bermakna secara statistik $(\mathrm{p}=0,63)$.

Pengukuran kadar albumin serum didapatkan rerata pada anak dengan tumor padat yang mengalami TCS $3,2 \mathrm{mg} / \mathrm{dL}$ (SD 0,501), yang bebas TCS 3,2 (SD 0,65) $\mathrm{mg} / \mathrm{dL}$, tetapi keduanya tidak berbeda secara statistik $(p=0,943)$. Pada anak dengan keganasan hematologi yang mengalami TCS $2,9 \mathrm{mg} / \mathrm{dL}$ (SD 0,67), yang tidak mengalami TCS 3,1 (SD 0,47), tetapi keduanya juga tidak berbeda bermakna $(\mathrm{p}=0,199)$. Terdapat 28 dari $40(70 \%)$ anak pada kelompok tumor padat dan 34 dari $43(79 \%)$ anak pada keganasan hematologi yang mengalami hipoalbuminemia. Pada kelompok tumor padat, 28 anak dengan hipoalbuminemia 14 (50\%) anak mengalami TCS. Pada kelompok keganasan hematologi, 34 anak dengan hipoalbuminemia, 10
$(29,4 \%)$ anak mengalami TCS dengan $(\mathrm{p}=0,403)$.

Gambar 1 menunjukkan gambaran gejala dari TCS yang paling banyak adalah dari $\mathrm{BB} / \mathrm{TB}<-2 \mathrm{SD}$ 20 anak, terdiri atas 12 dengan tumor padat dan 8 dengan keganasan hematologi, 7 klinis gizi buruk, 7 penurunan $\mathrm{BB}>5 \%$ dalam 1 bulan, 8 penurunan $\mathrm{BB} /$ TB $>2$ persentil mayor, dan 6 LiLA kurang dari P5.

Selama 6 bulan evaluasi, didapatkan 14 dari 40 (35\%) anak tumor padat dan 10 dari 43 (23,3\%) anak dengan keganasan hematologi yang mengalami

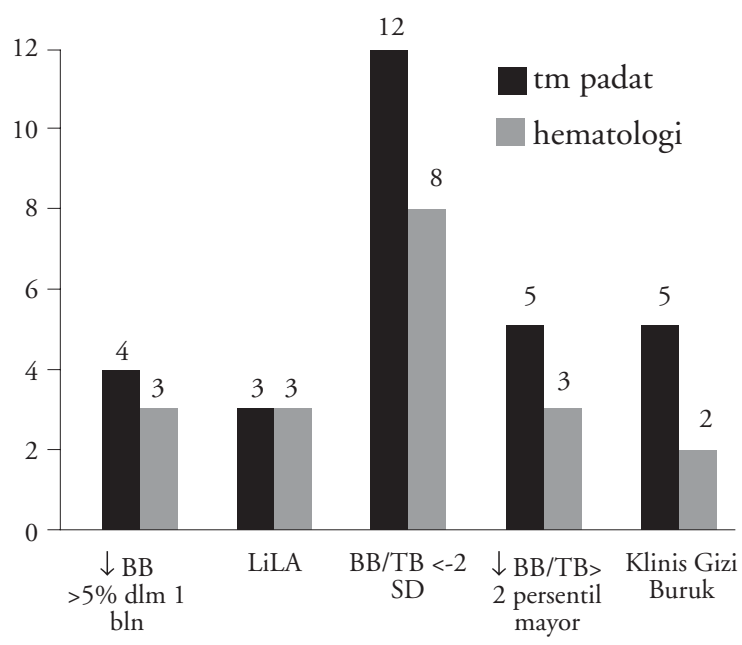

Gambar 1. Gambaran karakteristik gejala TCS 
TCS. Kelompok anak dengan tumor padat yang mengalami TCS, yaitu 7 retinoblastoma, 3 LMNH, 2 hepatoblastoma dan 2 nefroblastoma, Astrositoma, MPNST, PNET, dan neuroblastoma tidak ada yang mengalami TCS dengan $(\mathrm{p}=0,595)$. Kelompok anak dengan keganasan hematologi, 6 yang mengalami TCS, yaitu 4 AML dan 6 ALL. Pada CML dan mixed leukemia, tidak ada yang mengalami TCS dengan $(\mathrm{p}=0,117)$. Kurva EFS pada kedua kelompok tertera pada Gambar 2.

Gambar 2 menunjukkan persentase dari EFS terhadap kejadian TCS pada tumor padat dan hematologi. Mulai bulan kedua sudah didapatkan penurunan EFS untuk tumor padat dan untuk hematologi belum didapatkan penurunan. Penurunan EFS terhadap TCS pada keganasan hematologi mulai terjadi pada bulan ketiga. Sampai pada bulan keenam, EFS terhadap kejadian TCS pada tumor padat 65\% dan pada kelompok keganasan hematologi 76,7\%.

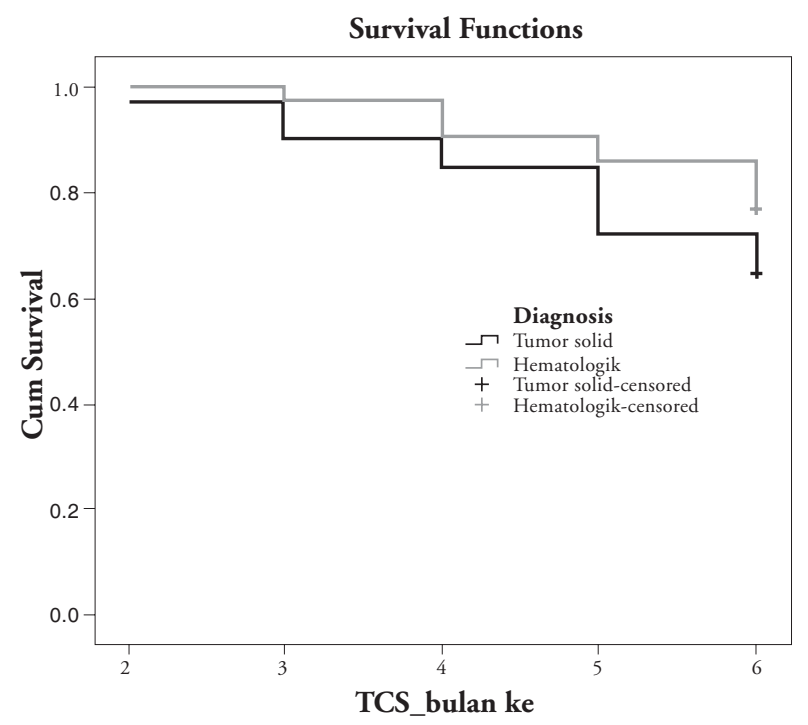

Gambar 2. Kurva Kaplan Meier untuk EFS terhadap TCS pada kedua kelompok
Rerata terjadi TCS pada tumor padat 4,4 bulan dan pada keganasan hematologi 4,9 bulan ( $p>0,05)$. Pada pasien dengan tumor padat, perbandingan EFS 6 bulan terhadap kejadian TCS lebih rendah daripada keganasan hematologi, tetapi setelah dianalisis dengan $\log$ rank menunjukkan tidak berbeda secara statistik $(\mathrm{p}=0,207)$.

\section{Pembahasan}

Di Amerika Serikat, insiden kanker anak paling banyak adalah leukemia (25\%), diikuti tumor susunan syaraf pusat (17\%), neuroblastoma (7\%), limfoma non-Hodgkin (LMNH) (6\%), nefroblastoma (6\%), limfoma Hodgkin (LMH) (5\%), rabdomiosarkoma (3\%), retinoblastoma (3\%), osteosarkoma (3\%), dan Ewing sarkoma (2\%). Proporsi laki-laki sedikit lebih banyak daripada perempuan. ${ }^{49}$ Di negara berkembang, keganasan hematologi akut paling banyak adalah acute lymphocytic leukemia ALL (83\%), acute myelogenous leukemia (AML) (17\%). Leukemia kronik mencapai $3 \%$ dari seluruh keganasan hematologi. ${ }^{13}$

Di antara 83 anak, 43 didapatkan anak dengan keganasan hematologi, ALL 76,7\%, AML 16,3\%, CML 4,7\%, dan mixed leukemia 2,3\%. Untuk kejadian tumor padat didapatkan retinoblastoma $47,5 \%$, LMNH 20\%, nefroblastoma 15\%, hepatoblastoma dan PNET masing-masing 5\%, dan astrositoma, MPNST, dan neuroblastoma masing-masing 2,5\%.

Rasio laki-laki dan perempuan pada keganasan hematologi akut adalah 1.15. Laki-laki mempunyai prognosis yang lebih buruk terkait timbulnya relaps testis, hiperleukositosis, organomegali, kejadian leukemia sel $\mathrm{T}$, dan massa mediastinum. ${ }^{14} \mathrm{Kami}$ mendapatkan perbedaan sebaran jenis kelamin antara tumor padat dan hematologi. Anak laki-laki yang menderita keganasan hematologi 76,7\% dibandingkan dengan anak perempuan $23,3 \%$. Pada anak dengan tumor padat, sebaran antara laki-laki dan perempuan

Tabel 2. Perbandingan EFS 6 bulan terhadap TCS pada kedua kelompok

\begin{tabular}{|c|c|c|c|c|c|c|c|c|c|}
\hline \multirow{3}{*}{ Variabel } & \multirow{3}{*}{$\mathrm{n}$} & \multicolumn{2}{|c|}{ Bebas TCS } & \multicolumn{4}{|c|}{ Rerata } & \multicolumn{2}{|c|}{$\log \operatorname{Rank}$} \\
\hline & & \multirow{2}{*}{$\mathrm{n}$} & \multirow{2}{*}{$\%$} & \multirow{2}{*}{ Estimasi } & \multirow{2}{*}{ SE } & \multicolumn{2}{|c|}{ CI 95\% } & \multirow{2}{*}{$\chi^{2}$} & \multirow{2}{*}{$\mathrm{p}$} \\
\hline & & & & & & Bawah & Atas & & \\
\hline Tumor padat & 40 & 26 & 65,0 & 5,450 & 0,172 & 5,113 & 5,787 & \multirow{2}{*}{1,591} & \multirow{2}{*}{0,207} \\
\hline Hematologi & 43 & 33 & 76,7 & 5,744 & 0,110 & 5,528 & 5,960 & & \\
\hline
\end{tabular}


sama banyak. Kejadian TCS pada anak laki-laki dengan keganasan hematologi $(24,2 \%)$ lebih besar daripada anak perempuan $(20,0 \%)$. Pada tumor padat, kejadian TCS sama besar antara anak laki-laki dan perempuan.

Penelitian di Malawi pada pasien usia 1-16 tahun dengan berbagai jenis tumor disebutkan bahwa pengukuran LiLA $<\mathrm{P} 5$ lebih banyak menjaring anak yang mengalami malnutrisi daripada penilaian $\mathrm{BB} / \mathrm{TB}$ $<-2$ SD sesuai CDC 2000. Hak tersebut karena BB dipengaruhi oleh masa tumor atau organomegali sehingga tidak menggambarkan BB yang sebenarnya. ${ }^{4}$ Kami menggunakan data dari rekam medis 24 anak yang mengalami TCS. Terdapat 6 data yang mencantumkan ukuran LiLA, dan semuanya di bawah P5. Sementara itu, ditemukan 20 anak dengan gejala $\mathrm{BB} / \mathrm{TB}<-2 \mathrm{SD}$. Pemeriksaan status gizi saat awal diagnosis terdapat 23 anak dengan gizi kurang. Untuk menyingkirkan perancu itu, diperlukan pemantauan gejala TCS yang lain setiap bulannya. Pada gejala penurunan $\mathrm{BB} / \mathrm{TB}>2$ persentil mayor dan $\mathrm{BB}>5 \%$ dalam satu bulan harus dilihat juga penyebabnya, apakah ada pengangkatan massa tumor, adanya diare atau muntah sebagai efek samping dari obat anti kanker. Jika ada, diperlukan juga pemantauan gejala TCS yang lain tiap bulannya.

Status gizi pasien dinilai dengan pencatatan $\mathrm{BB}, \mathrm{TB}$, LiLA, dan klinis seperti muscle wasting, iga gambang, baggy pants. Setelah itu, diikuti selama 6 bulan, kemudian dianalisis dengan CDC 2000. Untuk penilaian LiLA, dinilai dengan standar NHANNES III karena mempunyai standar LiLA sampai anak usia 18 tahun. ${ }^{15}$ Penggunaan data sekunder dari catatan medis pasien mengakibatkan banyak data yang tidak lengkap dan tidak masuk dalam penelitian ini. Tidak semua catatan medis dilengkapi dengan data ukuran LiLA sehingga untuk pengamatan perbulan sulit digunakan. Lebih banyak digunakan BB/TB dengan banyak faktor perancu, seperti masa, organomegali, penimbangan BB dengan baju/pampers. Saat awal diagnosis pada kelompok tumor padat terdapat 33,3\% anak dengan status gizi baik yang mengalami TCS. Sementara itu, terdapat $38,5 \%$ anak dengan status gizi kurang yang mengalami TCS. Saat awal diagnosis pada kelompok keganasan hematologi terdapat 17,9\% anak dengan status gizi baik yang mengalami TCS. Sementara itu, terdapat 33,3\% anak dengan status gizi kurang saat awal diagnosis yang mengalami TCS.

Penelitian multisenter retrospektif di Amerika Serikat digunakan sampel lebih dari 3000 dengan berbagai tipe tumor, melaporkan penurunan berat badan tingkat sedang sampai berat pada 30\%-70\% tergantung tipe tumor, letak tumor, ukuran dan stadium. Kejadian penurunan berat badan terbesar didapatkan pada tipe tumor padat, seperti tumor lambung, paru, kolorektal, kepala, dan leher. Risiko menurun pada tumor payudara dan hematologi. ${ }^{16}$ Penelitian dengan menggunakan desain kohort retrospektif pada anak dengan keganasan yang dirawat di RSUP dr. Kariadi Semarang selama 3 tahun (2007-2010) menemukan prevalensi TCS pada tumor padat $(66,7 \%)$ lebih besar dari pada keganasan hematologi $(65,2 \%)$. Namun, tidak ada hubungan antara tipe tumor dengan TCS. ${ }^{17}$ Penelitian secara kohort prospektif di Amerika Serikat ditemukan kejadian kakeksia lebih dari 10\% dengan rerata angka tahan hidup 8 minggu pada 297 pasien anak dengan keganasan saluran cerna. Faktor risiko yang berpengaruh adalah gizi buruk dan hipermetabolik. ${ }^{18}$ Penelitian lain di Amerika Serikat yang menggunakan metode penelitian kohort prospektif, disebutkan rerata durasi kakeksi 24 minggu (SD 18.5) pada 170 orang dewasa dengan tumor pankreas. ${ }^{19}$ Penelitian retrospektif di Jepang disebutkan median observasi terjadinya TCS pada tumor saluran pencernaan 111 hari. $^{20}$

Selama pengamatan 6 bulan pada seluruh anak dengan keganasan baik tumor padat maupun hematologi yang dirawat di RSUP dr. Kariadi Semarang periode 2007-2012, prevalensi TCS 28,9\%. Pada tumor padat didapatkan prevalensi TCS (35\%), lebih besar daripada keganasan hematologi $(23,3 \%)$. Pada anak dengan tumor padat sudah didapatkan kejadian TCS sejak pengamatan bulan kedua. Sementara itu, pada keganasan hematologi didapatkan sejak pengamatan bulan ketiga. Didapatkan hasil EFS 6 bulan terhadap TCS pada anak dengan tumor padat $(65 \%)$ lebih kecil dibanding keganasan hematologi (76,7\%). Namun, perbandingan EFS 6 bulan terhadap kejadian TCS antara tumor padat dan keganasan hematologi tidak berbeda bermakna $(\mathrm{p}=0.207)$.

Keterbatasan dalam penelitian ini adalah jumlah sampel yang kurang, disebabkan beberapa pasien yang tidak dapat dijadikan sampel penelitian karena pasien datang ke sentra pelayanan kesehatan (RSUPN dr. Kariadi) dalam keadaan sudah terjadi kakeksi, drop out, atau dirujuk balik. Data rekam medis yang tidak mencantumkan BB dan TB atau albumin minimal satu kali selama 6 bulan juga dieksklusi. Adanya bias instrumen ini besar. Penilaian status nutrisi tiap bulan lebih banyak yang menggunakan $\mathrm{BB} / \mathrm{TB}$ dengan banyak biasnya, seperti tidak menggunakan alat 
penimbangan yang sama, penimbangan menggunakan baju/pampers, atau massa tumor/ organomegali pada keganasan hematologi. Pemeriksaan kadar albumin serum tidak didapatkan tiap bulan sehingga tidak bisa menggambarkan keadaan nutrisi tiap bulan. Faktor perancu lain, seperti efek samping dari terapi anti kanker yang berbeda pada tiap pasien, asuhan nutrisi di tiap bangsal yang tidak sama, tidak dapat dihindarkan. Faktor perancu, seperti staging tumor, status nutrisi gizi awal dapat kita minimalisir dengan cara menganalisis keseragaman data.

\section{Kesimpulan}

Prevalensi TCS selama pengamatan 6 bulan pada seluruh anak dengan keganasan yang dirawat di RSUP dr. Kariadi Semarang periode 2007-2012 sebesar $28,9 \%$. Event free survival 6 bulan terhadap kejadian TCS pada pasien dengan keganasan hematologi $(76,7 \%)$ lebih besar daripada tumor padat $(65 \%)$, tetapi kedua kelompok tersebut tidak berbeda secara statistik untuk terjadinya TCS. Rerata timbulnya TCS pada tumor padat 4,4 bulan dan pada keganasan hematologi 4,9 bulan namun kedua kelompok tersebut tidak berbeda secara statistik dan didapatkan kejadian TCS mulai pengamatan bulan kedua

\section{Daftar pustaka}

1. Tisdale MJ. Mechanisms of cancer cachexia. Physiol 2009;89:381-410.

2. Inui A. Cancer anorexia-cachexia syndrome: are neuropeptides the key? Cancer Res 1999;59:4493-501.

3. Vollmers HP. Natural antibodies and cancer. J Autoimmunity 2007;29:295-302.

4. Israel T. Nutritional status at admission of children with cancer in Malawi. Amsterdam: University of Amsterdam; 2010.

5. Jurdana M. Cancer cachexia-anorexia syndrome and skeletal muscle wasting. Radiol Oncol 2009;43:65-75.

6. Hulst J, Joosten K, Zimmermann L, Buuren S, Vuller HB, Tibboel D, dkk. Malnutrition in critically ill children: from admission to 6 months after discharge. Clinical Nutrition. 2004;23:223-32.
7. Tisdale MJ. Molecular pathways leading to cancer cachexia. Physiol 2005;20:340-8.

8. Inui A. Cancer anorexia-cachexia syndrome: current issues in research and management CA Cancer J Clin 2002;52:72-91.

9. Baker S. Protein-energy malnutrition in the hospitalized patient nutrition in pediatrics basic science and clinical applications. Edisi ke-3. London: BC Decker Inc; 2003.h.910-6.

10. Rocha GA, Rocha EJ, Martins CV. The effects of hospitalization on the nutritional status of children. J de Pediatr 2006;82:70-4.

11. Nasar SS, Susanto JC, Lestari ED, Djais J, Prawitasari. Malnutrisi di rumah sakit. Dalam: Sjarif DR, ED EDL, Mexitalia M, Nasar SS, penyunting. Nutrisi pediatrik dan penyakit metabolik. Edisi ke-1. Jakarta: Badan penerbit IDAI; 2011.h.165-74.

12. Mosby TT, Barr RD, Pencharz PB. Nutritional assesment of children with cancer. J Pediatr Oncol Nurs 2009;26:186-97.

13. Kupfer GM. Chilhood cancer epidemiology. 2013. Diakses pada Maret 2014. Didapat dari: http://emedicine. medscape.com.

14. Permono B, Sutaryo, Ugrasena I, Windiastuti E, Abdulsalam M. Buku Ajar Hemato-Onkologi Anak. Ikatan Dokter Anak Indonesia. Badan Penerbit IDAI; 2005.

15. Gibson RS. Principles of nutritional assessment. Edisi ke-2. New York: Oxford Unive Press;2005.

16. Dewys WD, Begg C, Lavin PT. Prognostic effect of weight loss prior to chemotherapy in cancer patients. Eastern Cooperative Oncology Group. Am J Med 1980;1:491-7.

17. Mexitalia M, Sari HK, Sudarmanto B. Hubungan antara tipe tumor dengan tumor cachexia syndrome pada pasien anak dengan keganasan. Med Hosp 2012;1:37-41.

18. Bosaeus I, Daneryd P, Lundholm K. Dietary intake, resting energy expenditure, weight loss, and survival in cancer patients. J Nutr 2002;132:3465S-6S.

19. Fearon KC VA, Hustead DS. Definition of cancer cachexia: effect of weight loss, reduce food intake, and systemic inflammation on functional status and prognosis. Am J Clin Nutr 2006;83:1345-50.

20. Ogiwara H. Prognostic indications for survival in cancer cahexia on gastrountestinal tract. Diakses pada Maret 2014. Diunduh dari: http://myopenarchive.org. 